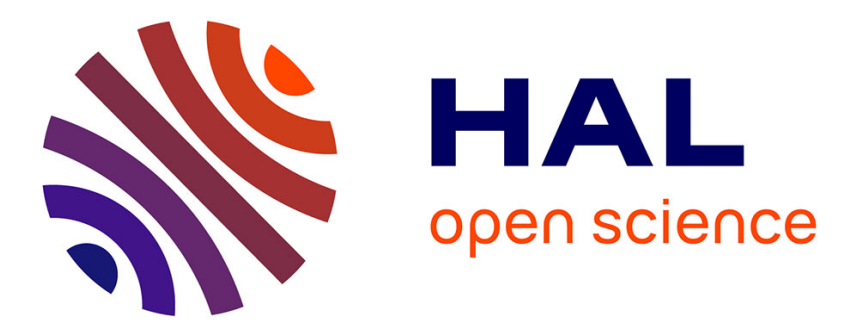

\title{
THE RESPONSE OF HOMOGENEOUS AND LAMINATED METALLIC SHEET MATERIAL TO BALLISTIC IMPACT
}

\author{
R. Woodward, S. Tracey, I. Crouch
}

\section{- To cite this version:}

R. Woodward, S. Tracey, I. Crouch. THE RESPONSE OF HOMOGENEOUS AND LAMINATED METALLIC SHEET MATERIAL TO BALLISTIC IMPACT. Journal de Physique IV Proceedings, 1991, 01 (C3), pp.C3-277-C3-282. 10.1051/jp4:1991339 • jpa-00250482

HAL Id: jpa-00250482

https://hal.science/jpa-00250482

Submitted on 1 Jan 1991

HAL is a multi-disciplinary open access archive for the deposit and dissemination of scientific research documents, whether they are published or not. The documents may come from teaching and research institutions in France or abroad, or from public or private research centers.
L'archive ouverte pluridisciplinaire HAL, est destinée au dépôt et à la diffusion de documents scientifiques de niveau recherche, publiés ou non, émanant des établissements d'enseignement et de recherche français ou étrangers, des laboratoires publics ou privés. 
Colloque C3, suppl, au Journal de Physique III, Vol. 1, octobre 1991

\title{
THE RESPONSE OF HOMOGENEOUS AND LAMINATED METALLIC SHEET MATERIAL TO BALLISTIC IMPACT
}

\author{
R.L. WOODWARD* , S.R. TRACEY * and I.G. CROUCH* \\ *DSTO Materials Research Laboratory, P.O. Box 50, Ascot Vale, \\ Victoria, 3032, Australia \\ * Royal Armament Research and Development Establishment, \\ Chertsey, Surrey, Great-Britain
}

\begin{abstract}
Résumé - On présente des résultats d'impacts sur une large gamme de cibles métalliques homogènes ou stratifiées. Il est démontré que les limites balistiques sont plus élevées dans les cibles stratifiées que dans les cibles homogènes, montrant que la stratification à une résistance suffisante pour rompre en tension. Tandis que dans les matériaux homogènes, la plus grande partie de l'énergie est consommée en accélération et cisaillement d'un bouchon, dans les stratifiés, l'élongation de chaque feuille unitaire absorbe une énergie considérable.
\end{abstract}

\begin{abstract}
Results are presented of ballistic impacts on a range of laminated and homogeneous metal targets. It is demonstrated that higher ballistic limits are achievable in laminated targets than in homogeneous targets for cases where the homogeneous target fails by a low energy mechanism, provided that the laminate has sufficient resistance to fracture in tension. Whereas in homogeneous targets most of the energy is consumed in the acceleration and shearing of a plug, in laminates the debonding and stretching of rear plates absorbs considerable energy.
\end{abstract}

1. Introduction

Aluminium laminates possess several advantages over homogeneous metals for construction of stiff lightweight structures, two of which are damage tolerance and potential higher resistance to ballistic perforation $[1,2]$. Examination of the ballistic performance of laminates has involved attempts to model the deformation as a two stage process where a process of plug acceleration is followed by delamination and bending and stretching deformation of the rear layers [3]. Such processes can be simulated individually in straight forward mechanical tests which characterize laminate behaviour in compression, tension, bending and shear [4]. Methods have also been developed which allow delamination processes to be studied and the work of delamination to be characterized [5]. Furthermore, material and geometrical parameters have been identified [6] which control the perforation behaviour of adhesivelybonded aluminium, laminates.

In the present work attention is directed at characterizing the principal energy absorbing deformation mechanisms in the perforation of sheet targets. By using homogeneous and both bonded and unbonded laminated targets of several aluminium alloys and bond characteristics it is possible to identify the ballistically better configurations and to describe quantitatively the redistribution of the impact kinetic energy into plastic deformation.

\section{Experimental Details}

Six experimental laminates were manufactured for this comparative study and their respective constituents are listed in Table I along with some physical data. The singular commonality between the laminates is that the metallic content was selected to be equivalent to approximately $6 \mathrm{~mm}$ of aluminium alloy, with all target areal densities 
being in the range 17 to $19.5 \mathrm{~kg} \mathrm{~m}^{-2}$. The series L9, L12 and L28, was similarly constructed of bare, $1 \mathrm{~mm}, 7075-\mathrm{T} 6$ sheet with the paste adhesive Hysol 9309.3 (NA), but differed in adhesive thickness and/or fibre content. The fibre used was Kevlar 49 in the form of a plain weave fabric. Laminates M1 and M3, whilst made of the different parent alloys 2024-T351 and the aluminium-lithium alloy 2090-T8E respectively, were both constructed using $1.6 \mathrm{~mm}$ sheet material and the epoxy film adhesive FM73. An unbonded laminate of 2024-T351 series alloy, D1, and homogeneous plates of 7075T6 alloy, D10, and of 2024-T351 alloy, D9, were also tested. Details of the laminating procedure have been described in earlier work $[1,3-6]$. Longitudinal tensile property data are given for all metal constituents, the laminates and the thick homogeneous reference target materials in Table II.

Table I - Laminate Details

\begin{tabular}{|c|c|c|c|c|c|c|}
\hline Designation & Alloy & $\begin{array}{l}\text { No of } \\
\text { Layers }\end{array}$ & $\begin{array}{l}\text { Layer } \\
\text { Thickness } \\
(\mathrm{mm})\end{array}$ & Adhesive & $\begin{array}{l}\text { Bondline } \\
\text { Thickness } \\
(\mu \mathrm{m})\end{array}$ & $\begin{array}{l}\text { Volume } \\
\text { Density } \\
\left(\mathrm{kg} \mathrm{m}^{-3}\right)\end{array}$ \\
\hline L9 & $7075-\mathrm{T} 6$ & 6 & 1.02 & HYSOL & 57 & 2687 \\
\hline $\mathrm{L} 12$ & $7075-\mathrm{T} 6$ & 6 & 1.02 & $\begin{array}{l}\text { HYSOL } \\
+ \text { KEVLAR }\end{array}$ & 414 & 2379 \\
\hline L28 & 7075-T6 & 6 & 1.02 & HYSOL & 414 & 2353 \\
\hline M1 & 2024-T351 & 4 & 1.59 & FM73 & 212 & 2570 \\
\hline D1 & 2024-T351 & 4 & 1.59 & UNBONDED & - & 2800 \\
\hline M3 & 2090-T8E & 4 & 1.59 & FM73 & 147 & 2503 \\
\hline
\end{tabular}

Table II - Longitudinal Tensile Properties of (a) Constituent Sheets. (b) Laminates and (c) Reference Plates

\begin{tabular}{|c|c|c|c|c|c|}
\hline & Material & $\begin{array}{l}\text { Thickness } \\
(\mathrm{mm})\end{array}$ & $\begin{array}{c}0.2 \% \text { P.S. } \\
(\mathrm{MPa})\end{array}$ & $\begin{array}{l}\text { U.T.S. } \\
(\mathrm{MPa})\end{array}$ & $E_{f}$ \\
\hline (a) & $\begin{array}{l}7075-\mathrm{T} 6 \\
2024-\mathrm{T} 351 \\
2090-\mathrm{T} 8 \mathrm{E}\end{array}$ & $\begin{array}{l}1.02 \\
1.59 \\
1.59\end{array}$ & $\begin{array}{l}530 \\
355 \\
510\end{array}$ & $\begin{array}{l}577 \\
520 \\
550\end{array}$ & $\begin{array}{l}0.14 \\
0.13 \\
0.09\end{array}$ \\
\hline (b) & $\begin{array}{l}\text { L9 }(7075) \\
\text { L12 }(7075) \\
\text { L28 (7075) } \\
\text { M1 (2024) } \\
\text { M3 }(2090)\end{array}$ & $\begin{array}{l}6.36 \\
8.09 \\
9.23 \\
7.09 \\
6.74\end{array}$ & $\begin{array}{l}493 \\
4.28 \\
342 \\
315 \\
475\end{array}$ & $\begin{array}{l}538 \\
503 \\
393 \\
416 \\
514\end{array}$ & $\begin{array}{l}0.15 \\
0.10 \\
0.14 \\
0.19 \\
0.10\end{array}$ \\
\hline (c) & $\begin{array}{l}\text { D9 }(2024) \\
\text { D10 (7075) }\end{array}$ & $\begin{array}{l}6.48 \\
6.60\end{array}$ & $\begin{array}{l}393 \\
518\end{array}$ & $\begin{array}{l}595 \\
571\end{array}$ & $\begin{array}{l}0.17 \\
0.16\end{array}$ \\
\hline
\end{tabular}

Perforation tests were carried out using flat-ended cylindrical steel projectiles, $12.5 \mathrm{~g}$ in weight and $12.7 \mathrm{~mm}$ in diameter. The critical velocity to perforate was taken as the average of two shots, closely spaced in velocity, one of which did and the other of which did not allow perforation by the projectile or ejection of target plug material. The energy required to perforate each target was the projectile kinetic energy at the critical velocity.

The delamination work during perforation can be estimated by measuring the total area of delamination and multiplying this by the adhesive peel strength. The bonded targets which had 
been perforated were baked at $230^{\circ} \mathrm{C}$ to denature the adhesive followed by peeling and measurement of delamination areas. Peel strengths were estimated from dynamic peel tests [5] and from published data as $3500 \mathrm{Jm}^{-2}$ for Hysol 9309.3 (NA), $1000 \mathrm{Jm}^{-2}$ for the bond containing Kevlar fibres, and $4000 \mathrm{Jm}^{-2}$ for the FM73 adhesive.

The work done in bending and stretching of the plates beyond the projectile diameter was estimated from measurements of the angle of bend as a function of radius for each plate of the laminates. A procedure due to Woodward et al. [7] is used with these measurements to calculate incremental values of bending and stretching work and thesc are summed. In each case a target impacted at a velocity near to the ballistic limit was chosen for sectioning so that the delamination, stretching and bending work terms might be compared to the perforation energy and so related to observed deformation/failure features. Approximations in the calculation of these terms should be consistent, so that data presented are comparable between different laminate configurations.

\section{Results and Discussion}

Listed in Table III are areal density, ballistic limit velocity, and perforation energy for all target types, as well as delamination area, delamination work, and bending and stretching work for the particular targets which were sectioned. Work terms not included in Table III are the plugging work and friction work, and for target type L12 the work of stretching the Kevlar.

The homogeneous 7075 aluminium target, D10, has a lower ballistic limit than any of the laminates constructed of 7075 aluminium. This is because of the occurrence of a discing type of failure $[8,9]$ which results from limited through thickness ductility and a consequent negligible contribution to the ballistic resistance by the rear of the target. A typical target is shown in Fig. 1. In the 7075 laminates the rear of the target bends away and remains intact, to undergo stretching deformation. This absorbs considerable energy and contributes to a higher ballistic resistance. As Table III shows, higher ballistic limits amongst the 7075 laminates correlate directly with higher stretching work, but do not really correlate with delamination energy. Table II shows that for the 7075 laminates the higher ballistic limits are observed with laminates of lower tensile strength; thus for ballistic impact the laminates cannot be treated as quasi-homogeneous plates, where energy absorbed is simply proportional to strength. Figure 2 shows a rear view and a section of the thin bondline 7075 laminate L9, and Figure 3 shows the thick bondline 7075 laminate L28 with far more bending of the lamina. The reason for the increased bending and hence substantially greater stretching work and higher ballistic limit with the thicker bondline is not clear, however it may be that for the thicker bondline the individual plates can bend more independently and effectively show a lower flexural stiffness. The failures in the examples of Figures 2 and 3 are only partially by plugging with fracture in the rear plates not being complete, because of the rapid redistribution of strcss, with the rear layers bending back and tearing in a process described by Crouch et al. [10]. It was observed that more layers are sheared through on the impact side in L12 (contains Kevlar) compared with L28. The presence of Kevlar in L12 increases the stiffness of the adhesive interlayer encouraging shearing rather than stretching [6]. The maximum perforation energy of the 7075 laminates is approximately the level expected from the strength of the homogeneous alloy if it did not fail by the discing mechanism.

The homogeneous 2024 aluminium alloy target, D9, shows a higher ballistic limit than the homogeneous 7075 plate even though it is of a lower strength alloy. This is because it is tougher and fails by plugging with the full thickness contributing to the ballistic resistance. For the 2024 aluminium the use of laminated configurations gives only a small increase in ballistic limit in one case, also correlating with a substantial increase in stretching work. That this case corresponds to zero delamination work (no bond) also confirms delamination is not important for the energy it absorbs, but for its ability to allow dishing of the rear target layers. A comparison of the data for the homogeneous plate, D9, with the bonded laminate, M1, which has the same ballistic limit suggests that for the extra work done in bending, stretching and delamination in the composite, an equivalent extra amount must be done in plug acceleration and deformation in the homogenous plate. Thus the change in mechanisms does not always give a net gain. 
翡。

8 ป

$\circ \quad \infty \quad \Xi-$

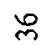

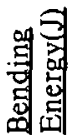

$\therefore \simeq$

$\pm$

$=\simeq 0$

으

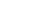

苟

善睃

8 म 2

$\circ$

$\stackrel{\infty}{\simeq}$

$\cong$

유

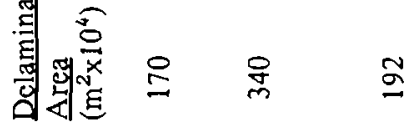

$\cong$

q

요

:

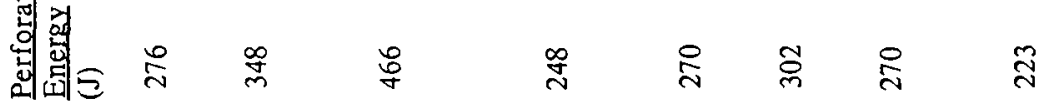

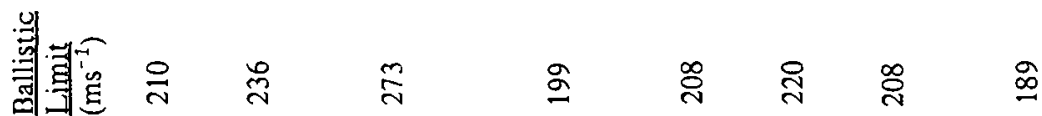

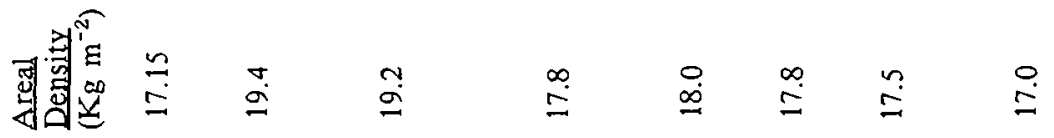

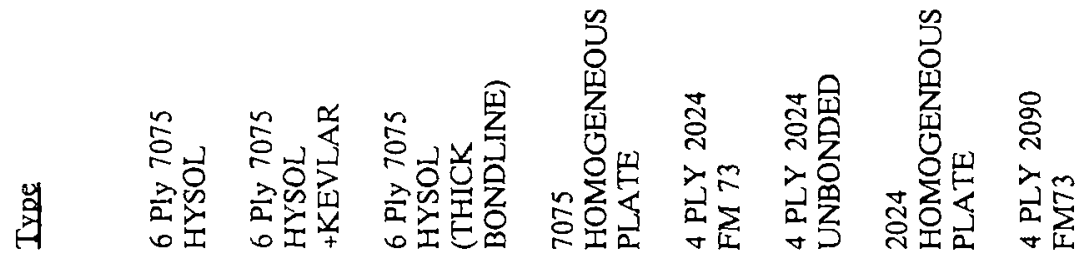

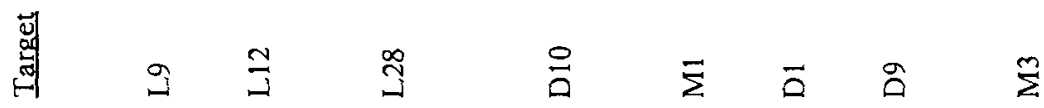




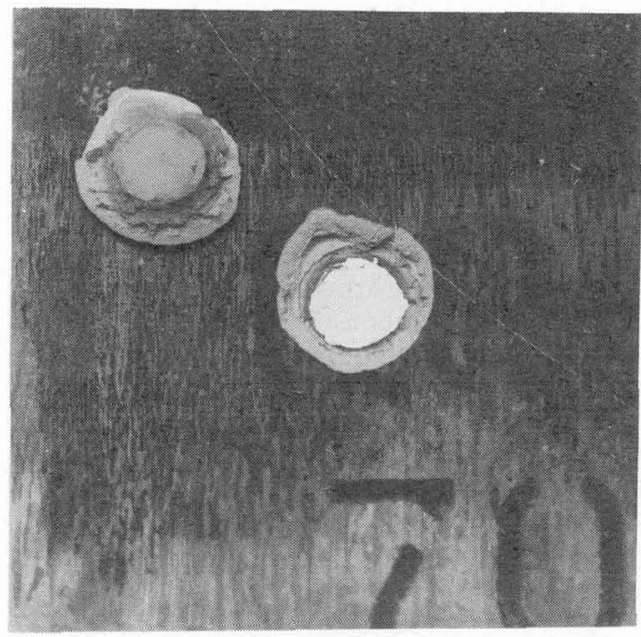

Fig. 1 - Failure of a 7075-T6 aluminium alloy plate by the discing mode.

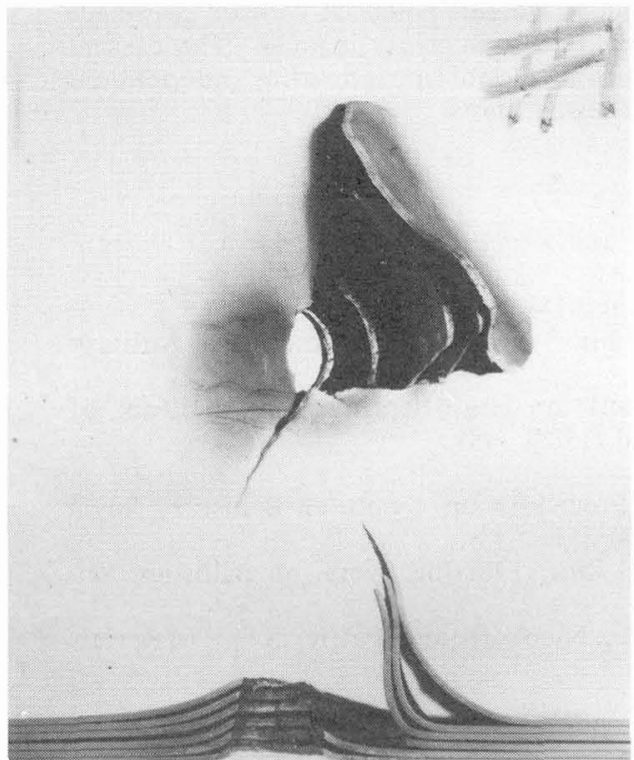

Fig. 2 - Bonded 6 ply $70 \overline{75}$ aluminium alloy laminate, L9, with the thin bondline showing the perforated target and a cross section.

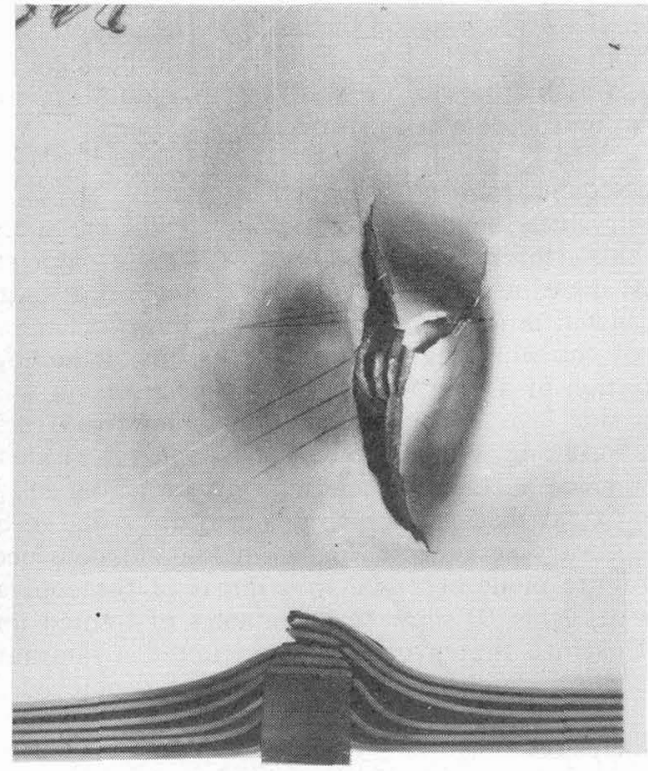

Fig. 3 - Bonded 6 ply 7075 aluminium alloy laminate, L28, with the thick bondline showing the perforated target and a cross section.

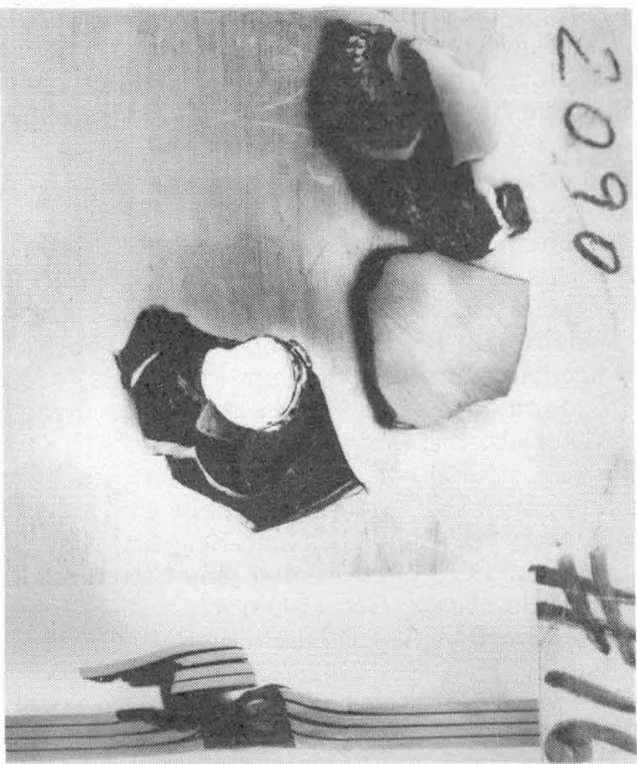

Fig. 4 - Perforated 4 ply aluminium-lithium alloy laminate, $M 3$, showing the fracture and ejection of plate material. 
The 2090 aluminium-lithium alloy laminate, M3, showed a low ballistic limit and this correlatcs with the occurrence of the discing type failure mode shown in Fig. 4. It appears that the more limited ductility in this alloy has allowed crack nucleation and propagation with limited bending and biaxial stretching of the rear of the target. The low ballistic limit correlates with little stretching work. The examination of the back of partly perforated plates showed the fracture initiated as biaxial tensile cracking at a ductility much lower than expected from quasistatic uniaxial tensile data in this material.

As is evident from the sectioned targets in Figs. 2 and 3, the laminate impact side layer plugs with very little bending and stretching, whereas successive plates towards the rear of the target bend and stretch more. Because of their greater stiffness negligible bending and stretching work is done in perforation of the homogencous targets, D9 and D10, so one can conclude that in laminated targets of similar ballistic limit, delamination and stretching work is substituted for some of the plugging work. Whereas in an homogeneous target deformation, shearing and acceleration of a plug is the major mechanism, in a laminate this principally occurs for only the impact side layer. The combination of lower stiffness in the laminate, particularly if the bond fractures, along with a difficulty of transfer of shear stress, displacement and fracture across the interface encourages bending and stretching of successive layers rather than plug shearing. To the extent that one is merely substituting one mechanism for another, a higher ballistic limit cannot always be expected in laminates, but does occur if the use of the laminate eliminates a poor failure mode observed in a target of the equivalent thickness parent material. Whilst the results of Table III show that laminates of limited toughness material will perform poorly, they also illustrate that properly constructed a laminate can enable the full potential ballistic resistance of a high strength material to be achieved.

\section{Conclusion}

The examination of ballistic data along with deformation studies of laminated and homogeneous metal targets has demonstrated that a major energy absorbing mechanism in the laminates is stretching of the layers, particularly those layers towards the nonimpact side of the laminate. Laminated targets may allow the full potential ballistic resistance of high strength materials to be realized provided their tensile ductility is good. The present results indicate that a limited bond strength and a thick bond line allowing independent stretching and bending of layers tends towards higher ballistic limits.

\section{References}

1. Crouch, I.G. Proc. Conf. on New Materials and Processes for Mechanical Design, Brisbane, May (1988) 21.

2. Vogelesang, L.G. and Gunnink, J.W. Materials and Design, I (1986) 287.

3. Woodward, R.L. and Crouch, I.G. Proc. 11 th Int. Symp. on Ballistics, Royal Military Academy, Brussels-Belgium May (1989) 301.

4. Crouch, I.G. and Woodward, R.L. Proc. Conf. on High Strain-rate Behaviour of Materials, Inst. Phys. Conf. Ser. No. 102, Oxford (1989) 481.

5. Simmons, M.J., Smith, T.F. and Crouch, I.G. Proc. 11th Int. Symp. on Ballistics, Royal Military Academy, Brussels-Belgium, May (1989) 351.

6. Crouch, I.G., Greaves, L.J. and Simmons, M.J. Proc. 12th Int. Symp. on Ballistics, San Antonio, Texas, Oct. (1990) 429.

7. Woodward, R.L., O’Donnell, R.J., Baxter, B.J., Nicol, B. and Pattie, S.D. Materials Forum, 13 (1989) 174.

8. Woodward, R.L. Metals Technology 6 (1979) 106.

9. Woodward, R.L. Int. J. of Impact Engng. 2 (1984) 121.

10. Crouch, I.G., Baxter, B.J. and Woodward, R.L. Int. J. of Impact Engng. 2 (1990) 19. 